https://doi.org/10.24101/logos.2019.75

Gauta 20191030

TATIANA HAJDER

Taras Shevchenko National University of Kyiv, Ukraine

Kijevo Taraso Ševčenkos nacionalinis universitetas, Ukraina

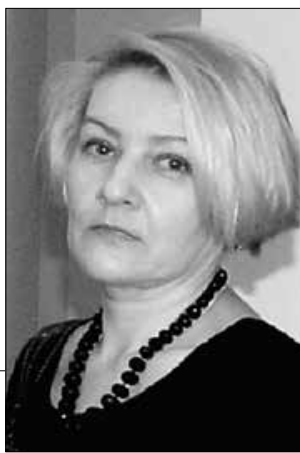

\title{
MITAS IR FILOSOFIJA SLAVY̨ MOKSLINĖS FANTASTIKOS ROMANUOSE
}

Myth and Philosophy in the Slavic Science Fiction Novel

\section{SUMMARY}

The article is dedicated to the problem of using reduced myth fragments at the formal level of fantastic literature. Despite the fact that the fantasy genre is the most consistent and traditional in the works of contemporary Ukrainian and Polish writers, the science fiction genre is still popular. Therefore, certain genetic links and codes remain within the scope of the researchers. Mythology may be the one of such a codes. The variants of the fragmentary use of myth are exemplified in the works of K. Trukhanovsky and O. Berdnyk. Slavic fantasy SF literature is overshadowed by the world-renowned classics of the genre. Nevertheless, it also deserves the close attention of researchers.

\section{SANTRAUKA}

Straipsnyje nagrinėjami sumažinto mito fragmentai formalios fantastinès literatūros lygmeniu. Mokslinės fantastikos žanras dabartinèje slavų (įskaitant ukrainiečių ir lenkų) grožinėje literatūroje vis dar populiarus. Be to, tai yra dažniausias ir tradiciškiausias žanras šiuolaikinių ukrainiečių ir lenkų rašytojų darbuose. Todèl mokslinių tyrimų akiratyje išlieka tam tikri genetiniai saitai ir kodai. Mitologija - tai vienas tokių kodų. Fragmentiško mito, kaip autoriaus filosofinės pozicijos komponento, panaudojimo variantai pateikiami K. Trukhanovskio ir O. Berdnyko darbuose. Slavų mokslinės fantastikos literatūrą gožia visame pasaulyje pripažinti klasikiniai šio žanro kūriniai, vis dèlto ši slavų literatūros sritis taip pat nusipelno tyrèjų dėmesio.

\section{INTRODUCTION}

Science fiction (SF) works have been ignored by serious literary studies, not

only among our society, but also among scholars of foreign Slavic countries, in- 
cluding the Polish scientific community for a long time. This is primarily connected with the fiction role interpretation in the history of literature as marginal. The only exception is the study of Stanislav Lem's work. Systematic scientific comprehension of fiction has began only in the second half of the XX century.

Recently, there is a real "scientific boom" in revealing the phenomenon of SF. Today, there is a growing research interest in the genesis and intertextual reading of fiction, because the science fiction writers contribution to the realm of literature concerning the problem of understanding the loss of certain civilization values and reflection on it is great.

The vast majority of scientific explorations, articles or monographs dedicated to the study of fiction, shed light on the following aspects: fiction as a specific artistic method (Yu. Mann, A. Mikhailova, V. Dmitriev, D. Volodikhin), the nature of fiction (T. Chernyshov, E. Kovtun, A. Niamtsu), of the fantastic imagery features of different periods and by different authors (Ts. Todorov, E. Brandis, D. Aydachich, B. Troha), language fiction problems, ontology of fiction (S. Lem, A. Sapkovsky, R. Herles, H. Borges). In the Ukrainian literary criticism a similar situation is observed but scholars are beginning to pay attention to this literature (O. Stuzhuk, O. Osadcha, S. Khorob,
V. Karatsupa) only at the turn of the XX and XXI centuries.

Despite the modern relativization of scientific discourse, it is too easy to equate science with religion as a system of belief-based ideas (The Transcendent Adventure: 1985: 3). The science fiction is also often easily placed at the poles of scientism and myth-making. That is why there are many misunderstandings. On the one hand, the term etymology and the creative work of eminent science fiction writers indicate a departure from religious views, but on the other hand, science fiction eagerly delves into subjects that were previously belonged to the realm of religious discourse: the birth and decline of civilization, the beginning and the end of all existence, creation of artificial existence and artificial reality, dichotomy of body and soul, origin of evil, status of messiah in society, culture and history, immortality, end of history.

The relevance of the article is the need for further comprehensive consideration of the means by which in the genre of scifi the artistic reconstruction of the past are made, the creation of a future picture or the reproduction of other world view models. The purpose of the article is to highlight individual genetic codes of the SF genre on the example of the Polish writer Kazimierz Trukhanowski's and the Ukrainian writer Oles Berdnyk's works.

\section{SCIENCE FICTION AS THE „SPIRIT OF THE TIMES“}

Science-fiction literature operates within the very different levels of our civilization's culture, ranging from ordinary entertainment to the most impor- tant ethical, cognitive, and philosophical issues that have concerned humanity since its earliest history (for example, works by Stanisław Lem, Strugacky 
brothers, Isaac Asimov). There are also very different views of science-fiction writers on the future of humanity. And here we come across both extremely optimistic, even idyllic, and catastrophic, post-apocalyptic visions that leave us with little hope. Also, in terms of literary nature, sci-fi prose shows a great variety. It does not lack the typically humorous or serious utopias or dystopias, as well as works that use fairy-tale themes or represent a very bleak picture.

Over the past 30-40 years, science fiction has become a niche, giving way to fantasy. The vast majority of high-profile fiction works are those where magic, monsters, or supernatural phenomena appear at the present time. Why is this happening? This is a "spirit of the times" manifestation and the fact that widespread admiration for space has passed is not the only reason. Science fiction is a very demanding genre. Not all writers possess a lot of scientific knowledge that is required in addition to fantasy to work in this genre. It is very difficult to create a masterpiece that would be equal to the scale and grandeur of the visions that were created in the so-called the "golden age" of the genre without prior theoretical training. Relatively little has been written about the conquest of space, the colonization of planets, and encounters with foreign civilizations. Today, the authors are more concerned about artificial intelligence and the changes that will take place here on Earth under the technological development influence. And there is nothing to hide, these are not optimistic predictions. Modern fiction is certainly closer to Huxley or Orwell than to joyful futurology.

In the 1970s, literary historians usually classified science fiction basing on the content sense and the writer's authorial style. Thus, there were distinguished such types of fiction: science fiction, philosophical, ironic-parody and philosophical-psychological. To a large extent, scholars have focused on the specific genre variants of "high" literature. So today, fiction - as a literary concept - is already defined as a meta-genre (A. Martuszewska, B. Trocha, M. Parowski, E. Kovtun, T. Chernysheva, O. Stuzhuk, S. Horob), dynamic and marked with a clearly pronounced "fantastic's" dominant, that is why human, civilizational and social problems are reflected on the content, meaning and form layer. However, certain genetic codes of the socalled SF can only be understood by considering the inheritance of the original classics elements of this genre. There may be problems in the analysis of works with multifaceted philosophical problems and complex fantastic symbolism after all. Such a classic (not only for Slavic literature), are certainly the works of Stanislav Lem, the author whom we owe the extraordinary richness of philosophical reflections in fantastic works. However, there are a few forgotten names that can also be attributed to the classics of the Lem's genre type in the Polish and the Ukrainian literatures. In these works, the main text-forming nucleus is philosophy and reflections on our existence. Such writers are Kazimierz Trukhanowski and Oles Berdnyk. 


\section{SF SLAVIC NOVEL: PHILOSOPHICAL AND MYTHOLOGICAL MOTIVES}

Polish science fiction traditions date back to the early twentieth century. In 1903, Jerzy Joułowski's novel, „Na srebrnym globie" („On the silver globe“), appeared, that was the first part of a trilogy about the moon, which became a kind of European science fiction gem. Its next parts are „Stara Ziemia“ (Old Earth) and "Zwycięzca" (The Winner). The novels and storytelling stories of the SF tradition were written subsequently, in particular by Władysław Umiński (Na drugą planetę), Antoni Lange (W czwartym wymiarze), Jan Lemański (Ofyara), Antoni Słonimski (Torpeda czasu), and even Stanisław Ignacy Witkiewicz (Pożegnanie jesieni) and Roman Dmowski (Dziedzictwo). However, it was only thanks to Stanislav Lem that Polish fiction began to conquer the world. After Lem, Janusz A. Zajdel, Czesław Chruszczewski, Adam Wiśniewski-Snerg and others began to write original, unlike anything else, works, and created their own, original, worlds, enriching this genre with interesting artistic and ethical and philosophical discoveries.

Ukrainian science fiction is much more modest in its inheritance, since the long period of Soviet life formed its own SF canon, the works of O. Berdnyk, V. Vladko, Victor and Vladimir Savchenko, O. Teslenko and others. The recent period of Ukrainian fiction demonstrates the decisive expansion of fantasy, albeit with elements of the sci-fi genre (Henry Lion Oldie, Marina and Sergei Dyachenko, etc.).
Fiction is a literary method that has very specific features. It helps to bring out some issues better in this form, but at the same time, this form is not always appropriate for some content. Everything is best embodied in science fiction's specifics. This was perfectly explained by Lem in one volume of "Fiction and Futurology", where he stated that a work cannot be considered fantastic if it eliminates the fantastic element. If you throw away what constitutes its fantastic essence, and this text still makes sense, it means that it is a bad work, because it was fantastic only with its outer packaging. For example, if you throw the thinking ocean out of the Solaris novel, everything will fall apart. Contemporary Polish journalist and science-fiction writer Rafał A. Ziemkiewicz notes that ",SF is a literary genre in which the created picture of the world is the main character and at the same time the main layer of the story. The old classic science fiction of the "golden age" were written not about adventures, but about the imaginary world, because the adventures of the heroes were played out quite schematically, and they themselves were (and still partly remain) not very expressive and not very complex characters" (Ziemkiewicz 1997 : 97-08.). And if the picture of the fantasy world is well constructed, that world can function as a metaphor. Such a fantastic world was created as a genre formality at first, and later it acquired the status of an allegory, a warning.

Conceptualizing the world with a focus on classical traditions is an attempt 
to return to the past in order to correct the future. Often this is the pragmatics of fiction texts, including science fiction, which often resorts to allegories and metaphor of myth in constructing a fictional world. The human desire to understand the surrounding nature, their place in the world and influence on the outside world should be in the first place among the constitutionally significant factors in the creation of texts with elements of fiction.

According to Andrzej Zgorzelski, fantastic occurs when the fictional world element denies the empirical order of this world (Zgorzelski: 1980). Science fiction, based mainly on empiricism, should not be called fantasy in that regard. However, it is quite different in the works such as The Star Corsair (1971), The Fire Rider (1989) by O. Berdnyk, or K. Trukhanovsky's Dzwony piekieł (1977).

The worlds created by writers are interspersed with anthropocentric philosophy, the core of which is man, his intellect, and his power of spirit. However, people do not value their world, threatening the existence of civilization with their wars, scientific experiments, irresponsible attitude to the environment and so on. It is in this philosophical statement that the profound metaphorical nature of their works lies.

K. Trukhanovsky's works are an expression of the desire for a philosophical and moral condemnation of modern civilization as a force hostile to nature and man, disrupting the age-old rhythm of being, a force that is doomed to instability and death. The author makes his diagnoses in the form of a parable, with the grotesquely deformed elements of the real world. He creates a futurological vision of civilization catastrophe and the revival of the human race in the ruins of ancient culture in the science-fiction novel The Bells of Hell (1977). In Trukhanovsky's novel, people eventually destroy everything and die as a species. Planet Earth has long been inhabited only by primitive forms of life, until it is inhabited by insects or other strange worms, which are devoid of many human qualities like spirituality, a sense of beauty, mercy, compassion. It is significant that the writer does not name the characters of his work by any names. All we know is that their planet was called Ethonia, so they are Ethons. And their entire voyage into space after escaping from their native dying planet (Hell) is a long way to the Promised Land, followed by the oppressive sound of Hell's Bells, as life on a spaceship is also hell. These creatures travel on the ship Argon II, which is a direct allusion to ancient mythology (a voyage on the Argo), on which the first fugitives die and the next generations are born. And those vile creatures, knowing the human civilization through the artefacts it has left behind - books, art, films, audio materials, etc. - begin to "become humanized", transformed until they become human. They are rapidly "evolving" by studying the culture of those who lived on planet Earth before them. Under the influence of this culture, into which they are immersed and infinitely penetrated, they are gradually transformed into humans not physically, but mentally. Together with knowledge about humans and their world, the Ethons embark on the same path as humans, subjecting themselves 
to all kinds of temptations until they are also threatened with death. And the Earth becomes hell again. The Polish writer remains true to his creative credo, uses the metaphor "Earth-Hell" already tried in other works further, and treats the humans and their world rather pessimistically.

Trukhanovsky's works is in the plane between science fiction and fiction. His science fiction is more a fantasy of irrepressible imagination, an orgy of oneiric style, a surreal expression. The writer himself explained the appearance of the novel "Dzwony Piekiel": "An important impetus for writing the Bells was the current affairs that concern the world humanity - the destruction of the natural environment of human. There is no need to stop there. [...] So:, I was prompted by the great love of the world, the greatest in my life, and the care of the world and its life, its preservation to write the Bells of Hell"(Thuchanowski 1977: 8-9).

Oles Berdnyk is a striking representative of Ukrainian prose in the second half of the twentieth century is. O. Berdnyk is a philosopher above all and the future interested him not by itself, but by close connection with the past. In his work the two traditions are successfully combined: science fiction of the $\mathrm{XX}$ century and the old Ukrainian fantasy. Complex social, philosophical, moral problems raised in the works of O. Berdnyk are developing the depth and intellectual load that can be found in R. Bradbury, K. Saymak, U. Le Guin, S. Lem, O. and B. Strugatsky. The writer refers in his works to the concept of the noosphere, in which the intellectual and sensual heritage of the ages are accumulated. There is no end to any- thing in the Universe, according to Berdnyk, so there can be no end to man. Intelligence, or spirit in Berdnyk's terminology, is formed not by a physical beginning but by a cosmic one. The structure of the universe as a whole and the essence of human being are identical. Dimension (infinity) and reason are one at its core. Man is not a simple reflection of natural processes, but a living creation of the universe, which must be activated through his own will.

O. Berdnyk's appeal to mythology is also of great importance. Rethinking ancient myths, he uses them as a modelling system of human thinking, activity in general, a kind of matrix for the reproduction of the heroic in everyday life. The novel Star Corsair is the most telling in this regard. The work reveals his awareness of various philosophical and religious systems (from Christianity to Confucianism through the esotericism of Blavatsky, Hindu-Buddhist teachings and Slavic paganism), worldview doctrines, the achievements of modern science and its tendencies of its further development (the author predicts the possibility to clone people). The confrontation between the two main characters, Horior and Kareos in the Star Corsair novel, can also be interpreted using mythology, however the east one. Horior, like the antimony of Ahriman, embodies the bright beginning that is directly encoded in his name. In the context of Avesta, it can be identified with AhuraMazda $^{1}$. Knowing the fact that the Greeks identified Ahura-Mazda with Zeus, then in contrast to Horior-Kareos, one can find parallels to the ancient 
myth of the Zeus's and Kronos's struggle. Kronos, in turn, is identified with the earth, Zeus - with the sky, what found its way in the novel of O. Berdnyk. The planet of Kareos becomes the embodiment of material values, the order of which is supported by Kareos, and the Asteroid Freedom - the place of freethinkers, headed by Horior.

The human spirituality development problems, the further development of human society, the spiritual and physical perfection of man, which is connected not only with the entry of human into the interplanetary and intergalactic space, but also the exit of human beyond his space of existence, beyond the threedimensional space, in multidimensionality is the main idea of the novel. Another novel, Fire Rider by Oles Berdnyk, was written from 1967 to 1989, despite its small volume. In these novels, the writer originally presents human values. They trace an attempt to rethink humanity's ontological path in philosophical, anthropological, aesthetic keys, and to find new levers in the formation of a harmonious, high-spirited personality.

If we can see the specifically transformed elements of the Pygmalion myth and the widely used white mythology and discourse of Scripture in Trukha- novsky's works, then Berdnyk tends to the Prometheus myth as well as to the fiery element. Fire is systematically present in various manifestations in all his works and is a distinct stylistic dominance at the level of motive in its textforming function. The writer goes back to folk-mythological, esoteric-mystical and Christian symbols, creating extravaganza novels as he outlined his works. Space travel, travel in time and space, extraordinary technologies - this is just a literary wrap to embody a deeply philosophical idea - what is the Human and where human goes in his/her evolution.

The sci-fi motifs are already so well known, moreover, they are so unrealistic that they are gradually replacing the traditional SF worlds, causing a disturbance to the sci-fi order. We can say that science-fiction, which uses metaphysical elements, again becomes fiction in this sense. Both the Polish and the Ukrainian writers tried to make sense of the tragic mistakes of our civilization through the lens of spiritual teachings of the East and the West. However, they did not attempt to use the literary convention of science fiction purely instrumental - as an excuse of their own interpretation of the Universe's presentation, other than the typical of classical science fiction vision.

\section{CONCLUSIONS}

Functions of the fantastic are quite complex and multifaceted (ontological, epistemological, prognostic, axiological, modelling, symbolic, etc.) in the twentieth century literature. The thematic range of fiction is also quite wide. However, the end of the twentieth century often prompted writers to create fantastic worlds because of their concern for the future of humanity. Therefore, the ethical and moral search for human is the common theme of science-fiction philosophical works. The use of various forms of conventions such as images, symbols, 
motives, techniques, and more is the one of the most significant features of fiction. That is what science fiction and mythology have in common. There are many works based on legendary mythological structures, because the poetics of the fantastic gives the authors the exclusive freedom to transform well-known plots, images and motifs. The works of such fiction writers as O. Berdnyk, K. Trukhanovsky, as well as many other Ukrainian and Polish, famous and little known authors (at least to mention such names as Marina and Sergey Dyachenko, Henry Oldie, or Polish - Adam WiśniewskiSnerg, Janusz A. Zajdel, J. Piekara, and others), testify that legendary mythological structures are the formal and se-

\section{Literature and References}

1. Ajdačič Deân Futuroslaviâ.Lìteraturoznavč̀̀ oglâdi pro futurofantistiku / K.:Vidavničopolìgrafičnij centr «Kiïvs'kij universitet», 2010 (Айдачич Деян, Футурославія. Дітературознавчі огляди про футурофантастику / К.: Видавничо-поліграфічний центр «Київський університет», 2010).

2. Âspers Karl., Smysl i prednaznačenie istorii / K. Âspers; per. s nem., Moskva, 1994. (К. Ясперс, Смысл и предназначение истории / К. Ясперс; пер. с нем. - 2 изд. - М.: Республика, 1994. - С. 32-37, 76-84).

3. Avesta v russkih perevodah (1861-1996 / [sost.,obŝ. red., primeč., sprav. razd. I. V. Raka)] SPB:RHGI, 1997 - (А веста в русских переводах (1861-1996) / [сост., общ. ред., примеч., справ. разд. И. В. Рака]. - СПб: РХГИ, 1997).

4. Babenko Lûdmila. G., Kazarin Ûrij. V. Lingvističeskij analiz hudožestvennogo teksta. Teoriâ i praktika, Moskva, 2003. (Л. Г. Бабенко, Ю.В. Казарин, Аингвистический анализ художественного текста. Теория и практика, Москва, 2003.)

5. Bp. Stanisław Wielgus «Wobec ofensywy ideologii neomarksizmu i postmodernizmu we mantic basis of many fantastic interpretations of well-known material.

The authors are trying to embody the traits that are inherent not in the individual society, but in the all humanity. The reality created by a rational-fantastic foundation is indicated by the intellectual comprehension of things.

Today, detailed studies of fiction are needed, especially considering its powerful development in recent years. Only the briefly raised questions of the artistic myth inheritance significance need clarification. We need to research separately the psychological mechanism of perception of the unusual, fantastic element's connection with the poetics of different literary currents.

współczesnym świecie». Warszawskie Studia Teologiczne, XVI/2003, 7-26.

6. Berdnik, O. (1989). Vognânij veršnik: Feêriii O./ Berdnik. - Kyiv : Molod’ [in Ukrainian]. (Бердник О. Вогняний вершник: Феєрії / О. Бердник. - К.: Мододь, 1989).

7. Horob, S. (2017). Žanrovì osoblivostì ukraïns'koï fantastiki kìncâ XX-počatku XXIÌ stolìttâ [The genre features of Ukrainian fiction of the end XX and beginning of the XXI century]. Ternopil` [in Ukrainian] (Хороб С. Жанрові особливості української фантастики кінця XX-початку XXI століття: автореф. дис. на здобуття наук. ступеня канд. філол. наук : спец. 10.01.01 - Українська література ॥ / С. Хороб. - Тернопіль, 2017).

8. Gemra Anna, Fantasy po polsku. Kilka uwag nad twórczością Andrzeja Sapkowskiego/ „Europa Orientalis" 2001, nr 20, s. 167-185.

9. Hajder Tatiana, Spiritual crisis as a sign of time: the projection of the problem in the fiction of the Slavic world/ Future Human Image, Volume 11, 2019, p. 32-41.

10. Fantastyka, fantastyczność, fantastyczny/pod red. Anny Martuszewskiej. Gdańsk: Wydawnictwo Uniwersytetu Gdańskiego, 1994. 
11. Lem Stanisław. „Fantastyka i futurologia”, t. 1-2, Kraków, Wydawnictwo Literackie, 1970.

12. Parowski Maciej, Czas fantastyki, Szczecin 1990.

13. Toynbee Arnold J., Studium historii. Skrót dokonany przez D.C. Somervella, tłum. J. Marzęcki, PiW, Warszawa. 2000.

14. Sapkowski Andrzej, «Piróg albo nie ma złota w szarych górach» / „Nowa Fantastyka” 1993, nr 5, s. 65-72.

15. The Transcendent Adventure: Studies of Reli-

\section{Endnotes}

1 In the Indo-Iranian era he was revered as the supreme god associated with heaven and at the same time he embodied the firmament of hea- gion in Science Fiction/Fantasy, red. R. I. Reilly, London 1985.

16. Truchanowski Kazimierz, Dzwony piekieł, PIW, Warszawa, 1977.

17. Ziemkiewicz Rafal A. - Polska fantastyka spotkanie trzech pokoleń/ „ETHOS” 1997 nr 4 (40) pp. 97-108.

18. Zgorzelski Andrzej, Fantastyka. Utopia. Science fiction. Ze studiów nad rozwojem gatunków. Warszawa 1980.

ven, and in the monastic doctrine of Zarathustra he became the only god and heavenly priest (Avesta in Russian translations (1997 : 426). 